\title{
“CLEAN HANDS” IN DERIVATIVE ACTIONS
}

\author{
JENNIFER PAYNE*
}

THE path to a successful derivative action for a minority shareholder is often a difficult one. In addition to demonstrating that one of the exceptions to the rule in Foss v. Harbottle ${ }^{1}$ applies, the courts have tended to add a number of additional requirements. One of these is the fact that the plaintiff must have "clean hands", i.e. that the shareholder will not be allowed to take advantage of an exception to the rule in Foss v. Harbottle if there is evidence of "... behaviour by the minority shareholder, which, in the eyes of equity, would render it unjust to allow a claim brought by the company at his instance to succeed". 3 This requirement needs further thought.

The equitable doctrine of clean hands is well established. ${ }^{4}$ Although the precise ambit of this equitable principle has been questioned, ${ }^{5}$ its continued existence is not doubted. ${ }^{6}$ It has been said that "[t]here must be some element of dishonesty or sharp

* Travers Smith Braithwaite lecturer in Corporate Finance Law, Merton College, Oxford. I am grateful to Dan Prentice and Roger Smith for their comments on an earlier draft. Any errors remain entirely my own.

${ }^{1}$ Foss v. Harbottle (1843) 2 Hare 461; Prudential Assurance Co. Ltd. v. Newman Industries Ltd. (No. 2) [1982] Ch. 204, 210.

2 See Gower, Principles of Modern Company Law, 6th edn., by Paul Davies (London 1997), p. 668; Gore-Browne on Companies, 44th edn., vol. 2, para. 28.8; Law Commission Consultation Paper No. 142, Shareholder Remedies, para. 5.18.

${ }^{3}$ Nurcombe v. Nurcombe [1985] 1 W.L.R. 370, 378 per Browne-Wilkinson L.J.

${ }^{4}$ The phrase was first used in Fitzroy v. Gwillim (1786) 1 T.R. 153, 154 per Lord Mansfield, although there it was regarded as equivalent to the maxim "he who seeks equity must do equity", a principle which is now regarded as distinct, relating to future rather than past conduct (cf. the clean hands doctrine). The first case in which the clean hands doctrine is recognised as a distinct maxim in its own right is Dering v. Earl of Winchelsea (1787) 1 Cox. Eq. Cas. 318. However, the origins of the clean hands concept can be seen in earlier cases, e.g., Jones v. Lenthal (1669) 1 Cas. in Ch. 154; Small v. Brackley (1707) 2 Vern. 602.

5 See, e.g., Z. Chafee, "Coming into equity with clean hands" (1947) 47 Mich. L.R. 877. It seems likely that since this maxim was first enunciated other equitable doctrines have developed to deal with many of the issues which would otherwise fall within the clean hands principle, such as equitable estoppel, laches, acquiescence etc. The ambit of the clean hands doctrine proper is therefore likely to have been reduced over time. Indeed, the House of Lords in Tinsley v. Milligan [1994] 1 A.C. 340 seem to regard it as equivalent only to the idea that a claimant who has been guilty of fraudulent or illegal conduct will forego assistance, a narrower view that adopted earlier in the century (e.g. Towers v. African Tug Co. [1904] 1 Ch. 558 which regarded acquiescence by the claimant as within the clean hands concept). The exact extent of the maxim is irrelevant for the purposes of this article since it is the role of this maxim however defined which will be discussed.

${ }^{6}$ E.g., Duchess of Argyll v. Duke of Argyll [1967] Ch. 302; Griffiths v. Griffiths [1973] 3 All E.R. 1155 ; NZ Netherlands Society "Oranje" Inc. v. Kuys [1973] 2 All E.R. 1222; J. Willis \& Son v. Willis [1986] 1 E.G.L.R. 62; Tinsley v. Milligan [1994] 1 A.C. 340. 
practice in the matter relied upon for saying that he does not come with clean hands" and examples of cases falling within this maxim involve individuals not being allowed to assert title to property where they have dealt with the property solely in order to defeat creditors $^{8}$ or to evade taxes ${ }^{9}$ because they "could not be allowed to take advantage of [their] own dishonesty". ${ }^{10}$ The purpose of this maxim is to prevent individuals profiting personally from their own misbehaviour. This makes sense in a bipartite relationship, such as that between trustee and beneficiary, where the individual is enforcing personal rights. In the context of company law this principle has obvious resonance where a member is suing to enforce a personal claim, another bipartite relationship, this time between the shareholder and wrongdoer. If there is an element of sharp practice or dishonesty in the shareholder's action then that personal claim may be denied. ${ }^{11}$

However the concept of clean hands, as with all equitable maxims, should not be "applied blindly and without reference to the facts of a given case". ${ }^{12}$ This reminder is particularly apt where the facts involve not a personal claim by a member but a derivative action brought by a member on behalf of the company. At this point it is less easy to see why the maxim should apply since the principles of separate legal personality, majority rule and the idea of a shareholder's vote as a piece of property ${ }^{13}$ combine to destroy the clean bipartite lines of the trust situation. If the wrongdoer's duty is owed to the company and the right to enforce that claim belongs to the company and not the minority shareholders, why should any conduct by a minority shareholder destroy the company's right of action?

There are two cases which are commonly cited in support of the proposition that the clean hands of the minority shareholder should be relevant in a derivative action: Towers v. African Tug Co ${ }^{14}$ and Nurcombe v. Nurcombe. ${ }^{15}$ Towers involved payments by directors of a company to the shareholders out of capital that, although honest, were nevertheless illegal. Three years after these payments were made two of the shareholders brought an action on behalf of the company seeking the repayment of these sums by the directors.

\footnotetext{
${ }^{7}$ Loosley v. National Union of Teachers [1988] I.R.L.R. 157, 162 per Sir Denys Buckley.

${ }^{8}$ E.g. Gascoigne v. Gascoigne [1918] 1 K.B. 223.

9 E.g. Re Emery's Investment Trusts [1959] Ch. 410.

10 Tinker v. Tinker [1970] 1 All E.R. 540, 541 per Lord Denning.

11 Towers v. African Tug Co. [1904] 1 Ch. 558, 572 per Cozens-Hardy L.J. (although see n. 19 and associated text); Re Flitcroft's Case (1882) 21 Ch. D. 519, 534-535 per Brett L.J.

12 Van Gestel v. Cann [1987] Times, 7 August per May L.J.

13 North West Transportation v. Beatty (1887) 12 App. Cas. 589.

14 [1904] 1 Ch. 558.

15 [1985] 1 W.L.R. 370.
} 
However, it was clear that both shareholders were well aware of the illegal nature of the dividend payments which they had themselves received and which remained "in their pockets" 16 at the time of the trial. The Court of Appeal unanimously held that in such circumstances the plaintiffs' action could not succeed:

I think that an action cannot be brought by an individual shareholder complaining of an act which is ultra vires if he himself has in his pocket at the time he brings the action some of the proceeds of that very ultra vires act. Nor, in my opinion, does it alter matters that he represents himself as suing on behalf of himself and others. ${ }^{17}$

In Nurcombe a husband and wife were the only two shareholders in a company. In their divorce proceedings it came to light that the husband had breached his duty as a director of the company in diverting a lucrative contract from the company into another company in which he held a controlling interest. The wife continued with the matrimonial proceedings when this issue came to light and the improper payment was taken into account in the lump sum awarded to the wife in the matrimonial proceedings. Subsequently the wife brought an action as minority shareholder on the company's behalf against her now ex-husband in relation to this breach of duty. Applying Towers, the Court of Appeal refused the derivative action:

In my judgment, [Towers] establishes that behaviour by the minority shareholder, which, in the eyes of equity, would render it unjust to allow a claim brought by the company at his instance to succeed, provides a defence to a minority shareholder's action. In practice, this means that equitable defences which would have been open to defendants in an action brought by the minority shareholder personally (if the cause of action had been vested in him) would also provide a defence to those defendants in a minority shareholder's action brought by him. ${ }^{18}$

In their Lordships' view, the behaviour of the plaintiff in this case, in accepting the lump sum payment and nevertheless going on to bring the derivative action, was sufficient to render it inequitable to allow that claim to proceed.

However, the decision in Towers needs to be treated with care. It is important to remember that at the time that case was decided there was some confusion concerning the distinction between actions by shareholders on behalf of themselves (and maybe other shareholders) for wrongs done to them personally and actions by

\footnotetext{
${ }_{17}^{16}$ [1904] 1 Ch. 558, 567 per Vaughan Williams L.J.

${ }^{17}$ Ibid.

18 [1985] 1 W.L.R. 370, 378 per Browne-Wilkinson L.J.
} 
shareholders on behalf of the company for wrongs done to the company. ${ }^{19}$ The term "representative action" was regularly used to describe both forms. ${ }^{20}$ In Towers, despite the fact that the Court of Appeal viewed the action as one on behalf of the company rather than the individual plaintiffs, they clearly did not regard the action by the plaintiffs as being identical in substance to a claim by the company itself. ${ }^{21}$ Rather, the claim by the shareholders on behalf of the company in Towers is regarded as an aggregation of the personal claims of the shareholders: "a shareholder, having money in his pocket which he knows is wrongfully there, ought not to be allowed to complain; and he cannot get any greater right of complaint because his action is, in form, an action by himself and all other the [sic] shareholders in the company". ${ }^{22}$

Only with the Court of Appeal's decision in Wallersteiner v. Moir (No. 2) $)^{23}$ was the term "derivative action" adopted to describe actions brought by minority shareholders on the company's behalf. More importantly, this change in terminology also helped to clarify the fact that in these circumstances the individual shareholder is not enforcing a right which belongs to them but which is, rather, vested in and therefore derived from the company. ${ }^{24}$ Post-Wallersteiner it should be clear that the derivative action is merely an equitable procedural device to enable the court to do justice to the company. In Nurcombe it was suggested that the situation in which the shareholder brings a derivative action on behalf of the company is analogous to that "in which equity permits a beneficiary under a trust to sue as plaintiff to enforce a legal right vested in trustees (which right the trustees will not themselves enforce), the trustees being joined as defendants". ${ }^{25}$ However, this is in substance a claim which belongs to the beneficiary, albeit that the form of the claim has changed. Post-

${ }^{19}$ It was common, as occurred in Towers, for the action of the shareholders on behalf of the company to be described as "an action ... by a shareholder suing on behalf of himself and all other shareholders against the company as defendants" ([1904] 1 Ch. 558, 571, per CozensHardy L.J). There seems to have been some confusion even at the time regarding the nature of this claim. For example, in Moseley v. Koffeyfontein Mines Ltd. [1911] 1 Ch. 73, reported seven years after Towers, the principle in Towers was relied on by counsel in relation to a personal claim by a shareholder and all three Court of Appeal judges in that case went out of their way to distinguish Moseley and Towers on that basis, see, e.g., [1911] $1 \mathrm{Ch} .73,78$ per Cozens Hardy L.J.

${ }^{20}$ See, e.g., Foss v. Harbottle (1861) 2 Hare 461, 491-492 per Sir James Wigram V.-C.

${ }^{21}$ [1904] 1 Ch. 558, 566 per Vaughan Williams L.J. Post-Wallersteiner v. Moir (No. 2) [1975] Q.B. 373, of course, the substance of a derivative action is regarded as identical to that of a claim by the company on its own behalf, albeit that the form is different.

22 Ibid., at p. 572 per Cozens-Hardy L.J.

23 [1975] Q.B. 373, 391.

${ }^{24}$ This has important consequences, so that, for example, shareholders can bring derivative actions in relation to wrongs which were done to the company before they became members (see, e.g., Seaton v. Grant (1867) L.R. 2 Ch. App. 459), something which is obviously not possible in relation to a personal action.

25 [1985] 1 W.L.R. 370, 378 per Browne-Wilkinson L.J. 
Wallersteiner it is clear that the shareholder's derivative action is a claim which in substance does not belong to the shareholder but to the company. The two situations are not analogous and to regard them as such is dangerous as it leads to the mistaken belief that equitable defences which exist between the shareholder personally and the wrongdoers can properly be relied on by the wrongdoers in a claim brought against them by the company, albeit that that claim is brought derivatively and not directly.

It is unlikely that much clarity will be introduced into this area if the proposals for the reform of derivative actions put forward by the Law Commission ${ }^{26}$ and broadly endorsed by the Company Law Review Steering Group ${ }^{27}$ are ever implemented. No mention is made of the requirement of clean hands as such in the Law Commission's Report, ${ }^{28}$ however this concept seems likely to be retained in relation to the suggested statutory derivative action. There are two ways in which this could occur. First, via the general recommendation that the courts take account of "all relevant circumstances without limit" 29 when determining whether to allow the derivative action to proceed ${ }^{30}$ and, second, via the specific recommendation that the courts take account of the good faith of the applicant. $^{31}$ No definition of good faith is provided as it is suggested, somewhat optimistically, that this concept is "generally readily recognisable". ${ }^{32}$ Much will depend on the interpretation of the courts. It is probable, however, that this concept will be interpreted as including bad faith which exists between the shareholder personally and the wrongdoer. ${ }^{33}$ The mistaken application of the clean hands doctrine in the context of derivative actions therefore seems likely to continue if the Law Commission's proposals are introduced.

${ }^{26}$ Law Com. No. 246, Shareholders Remedies, part 6.

${ }^{27}$ See DTI, Modern Company Law for a Competitive Economy: Developing the Framework (March, 2000) paras. 4.131-2 and DTI, Modern Company Law for a Competitive Economy: Final Report (June 2001) para. 7.46.

${ }^{28}$ Cf. Law Commission Consultation Paper No. 142, Shareholder Remedies, para. 5.18.

${ }^{29}$ Law Com. No. 246, Shareholders Remedies, paras. 6.73-6.74.

${ }^{30}$ This broad discretion is certainly wide enough to allow the court to continue to apply the clean hands principle developed in Towers and Nurcombe in the way in which it has, inappropriately it is suggested, been applied to date. There is certainly no suggestion in the Law Commission's Report that the courts should not take the concept of clean hands into account when deciding whether to allow a derivative action to proceed.

${ }^{31}$ Law Com. No. 246, Shareholders Remedies, paras. 6.75-6.76. The Law Commission's Report does not, however, suggest that good faith should be a prerequisite.

32 Ibid., para. 6.76 .

${ }^{33}$ This is not made explicit in the text. However, another of the Law Commission's stated factors recommends the court to have regard to the "interests of the company" (see n. 44 and associated text). If "bad faith" is only intended to cover situations in which the shareholder is acting contrary to the interests of the company, i.e. bad faith between the shareholder and the company, then the provision would presumably be otiose. It seems likely, therefore, that the good faith factor is intended to have broader application and to encompass issues of bad faith which exist between the shareholder and wrongdoer. 
The view put forward in Towers is difficult to accept in a postWallersteiner world where the distinction between personal actions and derivative actions is well understood. ${ }^{34}$ On closer inspection both Towers and Nurcombe actually involve two different, and distinct, issues which were not sufficiently unravelled in those cases: (1) should the company be allowed a claim against the wrongdoer(s)? and (2) should the shareholder(s) be allowed to profit from their own wrongdoing?

\section{The company's claim against the wrongdoer $(s)$}

Post-Wallersteiner it is clear that the claim against the wrongdoer(s) belongs to the company and that the derivative claim should be treated first and foremost as though it were equivalent to a claim by the company itself. As a result, the misbehaviour of the minority shareholders ought to be irrelevant. In cases involving actions actually brought by the company itself or by the liquidator of the company, whom the courts have never had any difficulty regarding as stepping directly into the company's shoes, the courts ignore the misbehaviour of a minority shareholder when determining whether to allow a derivative action to go ahead. ${ }^{35}$ The same result should occur where the action is brought derivatively, since although the form of the claim has changed the substance has not. As a general rule the cleanliness of the hands of the shareholders should be irrelevant in the courts' assessment of whether the derivative action should go forward since the issue for the court is doing justice to the company, and not to the shareholder, through the derivative action device.

However, there is a gloss to add to this otherwise straightforward proposition. In addition to asking whether the company has a right of action, the court may ask whether it should permit this shareholder to bring an action on behalf of the company. ${ }^{36}$ Take, for example, the situation in which A buys shares in a company, B Ltd. A is also the majority shareholder in C Ltd., which is a competitor of B Ltd. A brings a derivative action on behalf of B Ltd. against its directors. There are adequate grounds for this action on the basis of the directors' behaviour, but A's purpose is not to protect the company but to tie up management time and to provide a substantial distraction to B Ltd.'s business in

34 Prudential Assurance Co. Ltd. v. Newman Industries (No. 2) [1982] Ch. 204; Johnson v. Gore Wood \& Co. [2001] 2 W.L.R. 72.

${ }^{35}$ For example, in relation to illegal dividend payments, the court has no difficulty in allowing the claims against the directors to proceed even where some of the shareholders have received the payments in full knowledge of the illegality of those payments: Moxham v. Grant [1900] 1 Q.B. 88 .

${ }^{36}$ See e.g., Smith v. Croft (No. 2) [1988] Ch. 144, 170 per Knox J.; Nurcombe v. Nurcombe [1985] 1 W.L.R. 370. 
the hope of providing an advantage to C Ltd. Should the court allow A to bring this derivative action?

The problem is not A's improper motive per se, which should not be a basis for denying what is otherwise a valid derivative action. ${ }^{37}$ Rather, in attempting to obtain a collateral benefit for him or herself alone $\mathrm{A}$ is abusing the derivative action jurisdiction which exists to do justice to the company. In bringing the derivative action $\mathrm{A}$ is acting on behalf of the company, and in a solvent company this effectively means the other shareholders. If A has a unique interest in bringing the petition which is not shared by the other shareholders and if a majority of those shareholders are opposed to A's action then it is right and proper that the derivative action brought by A should be denied. ${ }^{38}$ This principle was articulated in the context of derivative actions by Knox J. in Smith v. Croft (No. 2) ${ }^{39}$ who was clear that shareholders do not have an indefeasible right to bring an action on the company's behalf and that it is proper for the court to have regard to the independent shareholders in determining whether to allow the derivative action to proceed. ${ }^{40}$ Therefore, the court could allow the independent shareholders in B Ltd. to determine whether it is in the interests of the company to let the derivative action brought by A to proceed. ${ }^{41}$

However, in certain circumstances, such as in very small companies, there may be no independent group of shareholders who can take this decision. In such circumstances the court is left with no assistance in determining whether A should be prevented from bringing this action on behalf of the company. If $\mathrm{A}$ is acting in his or her own self-interest and not in the best interests of the company then it may well be legitimate to deny the action on the ground that $\mathrm{A}$ is attempting to abuse the derivative action jurisdiction. An example of this situation is Barrett v. Duckett ${ }^{42}$ in

${ }^{37}$ Not only is the idea of denying someone an otherwise valid claim solely on the basis of an improper motive contrary to other, arguably analogous, areas of company law (see e.g., Bryanston Finance Ltd. v. De Vries (No. 2) [1976] Ch. 63, 75 per Buckley L.J.) but motive is also a concept which it is notoriously difficult for courts to ascertain, often being mixed and difficult to prove. The Law Commission has avoided the suggestion that an ulterior motive should of itself necessarily be sufficient (via the concept of bad faith) for the court to deny a derivative action: Law Com. No. 246, Shareholders Remedies, paras. 6.75-6.76.

${ }^{38}$ In an insolvent company a similar situation can arise regarding the motive for presenting a winding up petition. See e.g., Re Crigglestone Coal Co. Ltd. [1906] 2 Ch. 327; F. Oditah, "Winding up recalcitrant debtors" (1995) L.M.C.L.Q. 107, 123-130.

39 [1988] Ch. 144.

40 This is a view which has subsequently been endorsed by the Law Commission (Law Com. No. 246, Shareholders Remedies, paras. 6.88-6.90), albeit that the recommendation of the Law Commission is that the views of the independent organ should not be regarded as conclusive, but merely one of the factors to be taken into account by the courts. See also DTI, Modern Company Law for a Competitive Economy: Final Report (June 2001) paras. 7.46-7.51.

${ }^{41}$ Independence, for these purposes is measured by whether the shareholders would vote for the defendant directors in order to support them rather than for the benefit of the company: Smith v. Croft (No. 2) [1988] Ch. 144, 186 per Knox J.

42 [1995] 1 B.C.L.C. 243. 
which a derivative action brought by a shareholder against a director for diverting company money into bank accounts held by him for himself and his wife jointly was muddied by the fact that the plaintiff's daughter was engaged in a bitter matrimonial dispute with the defendant. There was no independent group of shareholders available in this very small company, since the only shareholders were the plaintiff shareholder and the defendant director. Although the Court of Appeal used the rather more emotive, and less appropriate, ${ }^{43}$ language of motive when denying the derivative action brought by the plaintiff, the thrust of the court's decision seems to be an aversion to allowing the plaintiff to misuse the derivative action process since the claim was not being pursued "bona fide on behalf of the company". ${ }^{44}$

It is possible, then, for the court to accept that the company may have a valid claim, but to deny the right to this shareholder to pursue that claim on behalf of the company because of some aspect of that shareholder's position. This principle does not involve a transfer of any equitable defences available between the plaintiff and the wrongdoer to the action between the company and wrongdoer. It does not fall within the clean hands doctrine. Rather, the court is here concentrating on its stated aim of using the derivative action to do justice to the company when determining that in particular circumstances it would be an abuse of that jurisdiction to allow an action brought by a particular shareholder to proceed.

\section{Should the shareholders be allowed to benefit from their own wrongdoing?}

In Towers the court was concerned that the shareholders bringing the derivative action had received, and indeed retained, illegal dividends in full knowledge of their illegality. Likewise, in Nurcombe, the court felt that: "In this action [the plaintiff] is in effect saying: although I have shared with the first defendant his illgotten gains, I want the court to order that he should pay over to [the company] his share of them plus my share so that I can have a chance of getting some more because of my status as a shareholder." ${ }^{45}$ In both cases the court was concerned to see that these shareholders did not profit personally from their

\footnotetext{
43 See n. 37.

44 [1995] 1 B.C.L.C. 243, 256 per Peter Gibson L.J. This principle seems to have been explicitly recognised by the Law Commission (Law Com. No. 246, Shareholders Remedies, paras. 6.776.79) which has suggested that the court should take account of the interests of the company when deciding whether to allow a derivative action to go ahead.

45 [1985] 1 W.L.R. 370, 377 per Lawton L.J.
} 
misbehaviour. This is a different issue from that of whether the company should have a claim.

The courts have traditionally adopted a conduct-based approach to the question of whether the shareholders should be affected personally, punishing only wrongdoing shareholders. ${ }^{46}$ In the context of illegal dividend payments, for example, trust concepts have been utilised ${ }^{47}$ so that shareholders with actual or constructive knowledge of the illegality of the payment can be ordered to indemnify the directors to the extent of the amounts they have received, ${ }^{48}$ but innocent recipients are exempt. ${ }^{49}$ This conduct-based approach has also been enshrined in statute. ${ }^{50}$ A good example of this approach is Moxham v. Grant, ${ }^{51}$ reported four years before Towers. In that case the directors of the company made illegal distributions to the shareholders, to which the shareholders unanimously agreed. When the company was subsequently wound up the liquidator brought an action whereby the directors were ordered to compensate a company for the whole of an illegal dividend paid while they were directors. In addition it was held that the directors could recover from each member who knew or ought to have known of the circumstances which made the dividend illegal the amount of dividend paid to that shareholder. If the confusion over the nature of the derivative claim in Towers is removed, and it is properly regarded as a claim belonging to the company, as the claim was in Moxham, then the two strands which

${ }^{46}$ By comparison, the suggestion in Bairstow v. Queens Moat Houses plc (CA), [2001] EWCA Civ 712, [2001] 2 B.C.L.C. 531 was that, in the context of unlawful dividend payments, even innocent shareholders could be liable to repay those dividends to the company. It was suggested that all shareholders (including therefore innocent shareholders) would receive an unmerited windfall if the amounts of the unlawful dividends which the shareholders had received in the past were then restored to the company by the directors and were again distributed, this time lawfully, by way of dividend. No view was reached on the merits of this issue in Bairstow, but this argument does not seem strong. There is little or no case law support for such an argument. The few words put forward from Cotton L.J.'s judgment in Re Flitcroft's Case (1882) 21 Ch. D. 519 in support of this claim by counsel in Bairstow are poor support, being contrary to the express views of the other two judges in Re Flitcroft's Case and arguably not able to support the meaning suggested in any case, see, e.g., Segenhoe v. Akins (1990) 1 A.C.S.R. 691. In addition, in other areas of company law windfall payments to shareholders are clearly regarded as acceptable, e.g., Regal (Hastings) Ltd. v. Gulliver [1967] 2 A.C. $134 \mathrm{n}$. A better argument to reclaim the payments made to the innocent shareholders may be a restitutionary claim, subject to the change of position defence.

${ }^{47}$ Russell v. Wakefield Waterworks Co. (1875) L.R. 20 Eq. 474; Rolled Steel Products (Holdings) Ltd. v. British Steel Corporation [1986] Ch. 246, 297-298 per Slade L.J.; Precision Dippings Ltd. v. Precision Dippings Marketing Ltd. [1986] Ch. 447; for a recent example, see Allied Carpets Group plc v. Nethercott [2001] B.C.C. 81.

${ }^{48}$ E.g., Moxham v. Grant [1900] 1 Q.B. 88; Precision Dippings Ltd. v. Precision Dippings Marketing Ltd. [1986] Ch. 447; Hilton International Ltd. v. Hilton [1989] 1 N.Z.L.R. 442; Aveling Barford Ltd. v. Perion Ltd. [1989] B.C.L.C. 626.

49 E.g., Re Denham \& Co. (1883) 25 Ch. D. 752.

${ }^{50}$ Section 277(1) of the Companies Act 1985, which operates in parallel with the common law provisions (s. 277(2) and see Precision Dippings Ltd. v. Precision Dippings Marketing Ltd. [1986] Ch. 447).

${ }^{51}$ [1900] 1 Q.B. 88. 
should have been unravelled in Towers, but were not, become clear. The unclean hands of the shareholders should have personal consequences for them (they should repay the dividends which they knew to have been paid illegally), but should not have consequences for the company.

However, the neatness of this proposition hides the fact that in some circumstances, namely where the company is very small, as in Nurcombe, imposing personal consequences on the plaintiff shareholder will inevitably impact upon the company itself. This may arise if, in a very small company, the minority shareholder effectively promises the wrongdoer that he or she will not bring a claim against that wrongdoer. ${ }^{52}$ The minority shareholder may then be estopped from bringing a claim, and if no-one else exists to bring a claim on the company's behalf at that time then no derivative action will be possible. ${ }^{53}$ Although this is a relationship between plaintiff and wrongdoer, since this is a right which the wrongdoer can enforce personally against the shareholder, the practical effect of such an estoppel in very small companies will be to deny an action for the company. In the view of the court in Nurcombe the wife had a choice of either bringing the derivative action or continuing with her application for financial provision in the divorce proceedings. ${ }^{54}$ In choosing the latter course, a decision on which, in the view of the court, the husband relied in paying the lump sum, "she was as effectively barred from commencing the [derivative] action as she would have been if she had entered into a binding obligation not to sue". ${ }^{55}$ This does not involve an application of the clean hands doctrine, but is merely a practical consequence of dealing with a situation in which the size of the

52 Of course, the fact that a shareholder generally owes no duty to act in the best interests of the company leaves them free to make such a promise.

53 This is unlikely to prevent a subsequent shareholder, or indeed a liquidator in the event of the company being wound up, being allowed to bring a claim on the company's behalf in relation to that wrong at a later date because, although there is no direct authority on this point, it seems likely that a decision not to sue is not extinctive of the company's claim. A more extreme, but less likely, possibility would be for the court to regard the company as having taken a valid decision to ratify the transaction via the principle discussed in Multinational Gas and Petrochemical Co. v. Multinational Gas and Petrochemical Services Ltd. [1983] Ch. 258, 280 per May L.J, that "the unanimous decision of all the shareholders in a solvent company about anything that the company under its memorandum of association has power to do shall be a decision of the company". This analysis is of no assistance where the company is in liquidation or where, as in Towers, the directors are attempting to do something (such as pay an illegal dividend) which the company has no power to do, but may be applicable in a Nurcombe-type situation. The views of the wrongdoing majority shareholder (not to bring a derivative action) are already known and therefore the views of the minority shareholder are the remaining piece of the jigsaw in determining the company's position for this purpose. If this does occur then it is likely that the ratification will be regarded as extinctive of the company's claim so that no future shareholder, or liquidator, would be able to re-open this issue (see J. Payne, "A Re-examination of Ratification" [1999] C.L.J. 604, 616-617).

54 Browne-Wilkinson L.J. preferred to view the case as one of acquiescence rather than election but does not seem to have believed that this affected the principles to be applied (at p. 378).

55 [1985] 1 W.L.R. 370, 380 per Sir Denys Buckley. 
company dictates that the acts or views of the minority shareholder affect the company because no one else is left to bring an action on the company's behalf at that time.

\section{Conclusion}

Equitable defences, such as clean hands, which exist between a minority shareholder personally and a wrongdoer should not be available to a wrongdoer in an action brought against that wrongdoer by the company, whether that claim is brought directly or via the procedure of a derivative action. It is notable that the courts have already recognised that in an action under section 459 Companies Act 1985, which has been recognised as enabling the court to outflank the rule in Foss v. Harbottle in some circumstances, ${ }^{56}$ the cleanliness or otherwise of the plaintiff's hands is irrelevant in deciding whether to allow the action to proceed. ${ }^{57}$ While minority shareholders' misbehaviour might well have consequences for themselves, such as requiring the repayment of dividends known to have been paid unlawfully, those actions ought, in the normal course of events, to be irrelevant for the purpose of deciding whether to allow a derivative action to proceed. To the extent that circumstances have been suggested here in which a minority shareholder's situation or actions may affect the decision to allow a derivative action brought by that particular shareholder to proceed, these do not spring from the clean hands doctrine, but rather from the particular factual circumstances of the case or from an entirely proper desire on the court's part to use the derivative action only where it is necessary to achieve justice for the company.

${ }^{56}$ Re Saul D. Harrison \& Sons plc [1995] 1 B.C.L.C. 14, 18 per Hoffmann L.J.; Re Charnley Davies Ltd. (No. 2) [1990] B.C.L.C. 760.

${ }^{57}$ Re London School of Electronics [1986] Ch. 211. However, the cleanliness of the hands of the plaintiff will undoubtedly have a part to play in determining whether the activities complained of are, in fact, unfair, and also on the remedy which the court awards at the end of the day. 